\title{
Quality of Water for Livestock in Man-made Impoundments in the Northern High Plains
}

\author{
MARK A. RUMBLE
}

\section{Abstract}

Twenty-seven water quality parameters were measured in coal surface mine impoundments, bentonite surface mine impoundments, and livestock ponds in the Northern High Plains. Most impoundments were safe for use as a source for livestock drinking water. Eight water quality parameters were different $(\alpha \leq \mathbf{0 . 0 5})$ among the types of impoundments. Sulfate concentrations in some coal and bentonite surface mine impoundments were higher than recommended for safe livestock use. Total dissolved solids in bentonite surface mine impoundments may be higher than considered safe. Lead concentrations in some coal surface mine impoundments and livestock ponds exceeded the recommended safe levels for livestock drinking water.

Surface mining in the Northern High Plains left depressions that later filled with water. The use of these surface mine impoundments for livestock watering represents a potential benefit; however, little information is available pertaining to such a use. The quality of water in some coal surface mine impoundments may not be of suitable quality for watering livestock (Gilley et al. 1976).

Livestock ponds in the Northern High Plains were created by damming drainages. Usually, they have been found to contain water of suitable quality for livestock (Alsayegh et al. 1966, Soiseth 1975). This study investigated the quality of water in coal and bentonite surface mine impoundments and livestock ponds in the Northern High Plains as related to livestock drinking water. Whereas assessment of water quality can ensure a safe source of drinking water for livestock, other problems, such as animals becoming stuck in the mud of bentonite impoundments, still need to be solved.

\section{Study Area and Methods}

Three types of water impoundments were selected for this study in northeastern Wyoming, western South Dakota, and western North Dakota (Fig. 1). Twenty coal surface mine impoundments, 12 bentonite surface mine impoundments, and 9 livestock ponds were selected for study. The coal surface mine impoundments were near Beulah, N. Dak.; Gascoyne, N. Dak.; Firesteel, S. Dak.; and Sheridan, Wyo. Bentonite surface mine impoundments were located near Colony, Wyo. One or 2 livestock ponds were selected at each of these locations.

Twenty-seven water quality parameters were compared among impoundment types. During 1978, single grab samples from each surface mine impoundment and livestock pond were analyzed for aluminum, arsenic, cadmium, chromium, cobalt, copper, iron, mercury, lead, manganese, selenium, silica, and zinc by the U.S. Geological Survey Laboratory in Arvada, Colo. Nitrate, total Kjeldahl nitrogen (TKN), phosphorus, potassium, magnesium, sodium, calcium, sulfate, chloride, total dissolved solids (TDS), depth of $0.5 \%$ light penetration, $\mathrm{pH}$, bicarbonate, and carbonate samples were collected over a 3-year period (1976-1978) and the results of the analyses were averaged. Nitrate samples were filtered through a $0.45-\mu$ filter, and chilled to $4^{\circ} \mathrm{C}$. TKN samples were

\footnotetext{
The author is a research wild life biologist with the Rocky Mountain Forest and Range Experiment Station, Rapid City, S. Dak., in cooperation with the South Dakota School of Mines and Technology. The Station's headquarters is in Fort Collins, in cooperation with Colorado State University.

Manuscript accepted April 3, 1984.
}

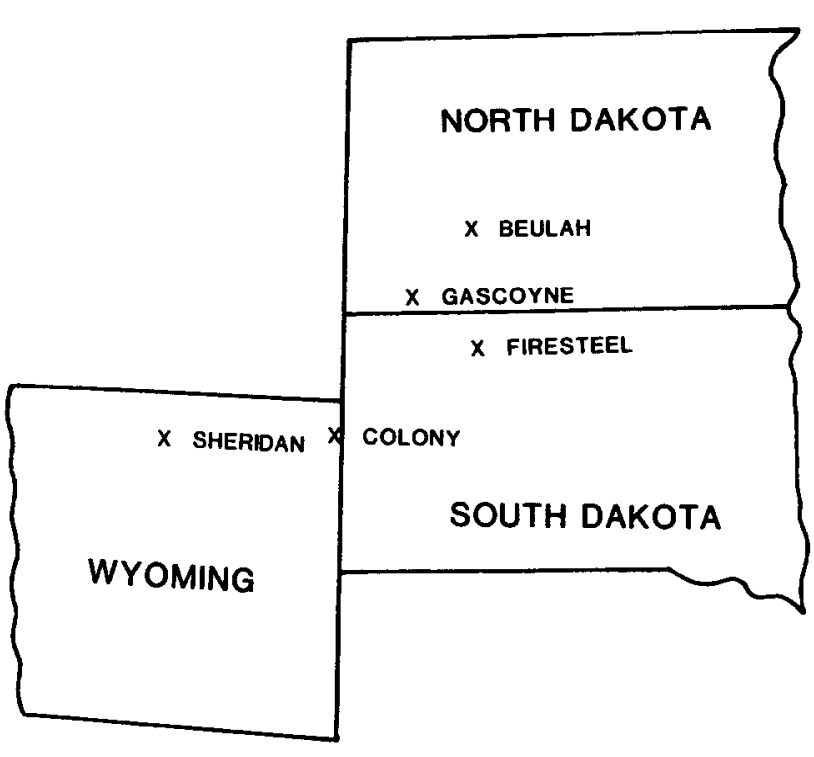

Fig. 1. Locations of water impoundments selected for this study.

acidified with sulfuric acid. All laboratory analyses were done by methods specified by the American Health Association (1975). Bicarbonate and carbonate were measured by titration, and depth of $0.5 \%$ light penetration was measured with an underwater photometer. Age of the impoundments was included in the analyses for interpretive purposes.

Data were subjected to one-way analysis of variance by the type of impoundment (Nie et al. 1975). Tukey's test and/or linear contrasts were used to determine where differences among impoundment types existed (Steel and Torrie 1960). All analyses were considered significant at $\alpha \leq 0.05$.

\section{Results}

\section{Impoundment Differences}

Age of the impoundments and 8 water quality parameters were different among the 3 impoundment types (Table 1). Age of the impoundments was different among all 3 impoundment types. Livestock ponds were the oldest, followed by coal surface mine and bentonite surface mine impoundments, respectively. Statistically, differences in the 8 other parameters between and among the 3 impoundment types were significant $(\alpha \leq 0.05)$, but not consistent. Total Kjeldahl in the 2 types of surface mine impoundments was similar but lower than levels in livestock ponds. Phosphorus levels were higher in livestock ponds than coal surface mine impoundments. Potassium was highest in the coal surface mine impoundments and lowest in the livestock ponds. Phosphorus and potassium concentrations in bentonite surface mine impoundments were not different from levels found in the other 2 types of impoundments. Bicarbonate concentrations were higher in coal surface mine impoundments and different only from levels found in the bentonite surface mine impoundments. The highest concen- 
Table 1. Water quality parameters that were significantly different $\alpha \leq 0.05$ ) among surface mine impoundments and livestock ponds on the Northern High Plains..$^{1}$

\begin{tabular}{|c|c|c|c|c|c|}
\hline $\begin{array}{c}\text { Parameter } \\
\text { (Units of measurement) }\end{array}$ & $\begin{array}{c}\text { Coal surface } \\
\text { mine impoundments } \\
x \pm \\
\text { (Range) }\end{array}$ & $\begin{array}{c}\text { Bentonite surface } \\
\text { mine impoundments } \\
\bar{x} \pm \text { SE } \\
\text { (Range) }\end{array}$ & $\begin{array}{c}\text { Livestock ponds } \\
\bar{x} \pm \mathrm{SE} \\
\text { (Range) }\end{array}$ & $\begin{array}{l}\text { Recommended } \\
\text { Maximum }\end{array}$ & Source \\
\hline Age of Impoundment (years) & $\begin{array}{l}24.85 \pm 2.58^{2} \\
(11.0-55.0)\end{array}$ & $\begin{array}{c}11.50 \pm 2.20^{b} \\
(4.0-26.0)\end{array}$ & $\begin{array}{l}41.22 \pm 6.22^{c} \\
(12.0-69.0)\end{array}$ & $\mathbf{N A}^{2}$ & \\
\hline Total Kjeldahl nitrogen (mg/l) & $\begin{array}{c}0.36 \pm 0.30^{\mathrm{a}} \\
(0.18-0.69)\end{array}$ & $\begin{array}{c}0.33 \pm 0.02^{\mathrm{a}} \\
(0.18-0.47)\end{array}$ & $\begin{array}{c}0.66 \pm 0.15^{b} \\
(0.34-1.31)\end{array}$ & See nitrate in Table 2 & \\
\hline Phosphorus (mg/l) & $\begin{array}{c}0.05 \pm 0.01^{\mathrm{a}} \\
(0.00-0.24)\end{array}$ & $\begin{array}{l}0.12 \pm 0.07^{\mathrm{a}, \mathrm{b}} \\
(0.01-0.93)\end{array}$ & $\begin{array}{c}0.26 \pm 0.11^{\mathrm{b}} \\
(0.01-1.10)\end{array}$ & NA & \\
\hline Potassium (mg/1) & $\begin{array}{l}22.75 \pm 2.04^{\mathrm{a}} \\
(11.0-48.0)\end{array}$ & $\begin{array}{l}17.50 \pm 2.10^{\mathrm{a}, \mathrm{b}} \\
(10.0-34.0)\end{array}$ & $\begin{array}{l}15.78 \pm 1.61^{b} \\
(10.0-23.0)\end{array}$ & NA & \\
\hline Bicarbonate (mg/l) & $\begin{array}{c}255.25 \pm 38.69^{\mathrm{a}} \\
(50.0-650.0)\end{array}$ & $\begin{array}{c}105.75 \pm 17.41^{\mathrm{b}} \\
(16.0-200.0)\end{array}$ & $\begin{array}{c}188.80 \pm 55.82^{\mathrm{a}, \mathrm{b}} \\
(16.0-450.0)\end{array}$ & $3,600 \mathrm{mg} / 1$ & Weeth (1973) \\
\hline Selenium $(\mu \mathrm{g} / \mathrm{l})$ & $\begin{array}{l}2.20 \pm 0.75^{\mathrm{a}} \\
(0.0-16.0)\end{array}$ & $\begin{array}{c}10.58 \pm 3.19^{b} \\
(3.0-32.0)\end{array}$ & $\begin{array}{l}1.22 \pm 0.15^{\mathrm{a}} \\
(1.0-2.0)\end{array}$ & $50.0 \mu \mathrm{g} / 1$ & EPA (1972) \\
\hline Carbonate $(\mathrm{mg} / \mathrm{l})$ & $\begin{array}{c}91.85 \pm 16.96^{\mathrm{a}} \\
(0.0-281.0)\end{array}$ & $\begin{array}{c}30.00 \pm 7.55^{b} \\
(0.0-76.0)\end{array}$ & $\begin{array}{l}96.00 \pm 22.80^{a} \\
(20.0-225.0)\end{array}$ & NA & \\
\hline Depth of $0.5 \%$ light $(\mathrm{m})$ & $\begin{array}{l}4.15 \pm 0.44^{\mathrm{a}} \\
(0.3-9.9)\end{array}$ & $\begin{array}{l}1.96 \pm 0.48^{b} \\
(0.0-4.7)\end{array}$ & $\begin{array}{l}2.50 \pm 0.56^{\mathrm{b}} \\
(0.1-5.5)\end{array}$ & NA & \\
\hline Magnesium (mg/l) & $\begin{array}{c}98.15 \pm 23.04^{n} \\
(5.0-365.0)\end{array}$ & $\begin{array}{c}26.91 \pm 12.00^{b} \\
(3.0-154.0)\end{array}$ & $\begin{array}{l}23.67 \pm 4.94^{b} \\
(10.0-60.0)\end{array}$ & $1,712 \mathrm{mg} / 1$ & Ballantyne (1957) \\
\hline
\end{tabular}

'Means with the same superscript letter for a given parameter are not different from each other $(\alpha \leq 0.05)$ as determined by Tukey's test.

2NA indicates a standard was not available.

trations of selenium and lowest carbonate concentrations were in bentonite surface mine impoundments. Both of these values were different from those of coal surface mine and livestock watering ponds, which did not differ. Depth of $0.5 \%$ light penetration and magnesium concentration were similar in bentonite surface mine impoundments and livestock ponds, and lower than coal surface mine impoundments.

The mean and range of concentrations of the 19 other water quality parameters measured were not different in the analyses of variance (Table 2). Although significant differences were not found, concentrations of some of these parameters exceeded recommended safe standards for livestock and/or wildlife drinking water. The maximum concentration of TDS in the bentonite sur- face mine impoundments was twice the recommended safe limit, whereas, the highest concentration in coal surface mine impoundments was at the recommended safe tolerance level (Olson et al. 1978). However, the average TDS concentrations for all 3 types of impoundments were considered acceptable for livestock drinking water. The highest concentration of sulfate found in bentonite impoundments was almost 4 times the recommended safe limit of $2,500 \mathrm{mg} / 1$ (Digesti and Weeth 1976). Sulfate levels twice the safe limit were found in some coal surface mine impoundments. However, average sulfate concentrations in all 3 types of impoundments were less than the recommended safe level. Maximum lead concentrations in all 3 types of impoundments exceeded the recommended safe level of $100 \mu \mathrm{g} / \mathrm{l}$ for livestock water (EPA 1972, Dyer

Table 2. Mean and range of measurements of water quality parameters from two types of surface mine impoundments and livestock ponds on the Northern High Plains.

\begin{tabular}{|c|c|c|c|c|c|}
\hline $\begin{array}{l}\text { Parameter } \\
\text { (Units of measurement) }\end{array}$ & $\begin{array}{l}\text { Coal surface } \\
\text { mine impoundments } \\
\frac{x}{\text { (Range) }}\end{array}$ & $\begin{array}{l}\text { Bentonite surface } \\
\text { mine impoundments } \\
\frac{x}{\text { (Range) }}\end{array}$ & $\begin{array}{c}\text { Livestock } \\
\text { ponds } \\
x(\text { Range })\end{array}$ & $\begin{array}{l}\text { Recommended } \\
\text { Maximum } \\
\text { for livestock }\end{array}$ & Source \\
\hline Aluminum $(\mu \mathrm{g} / \mathrm{l})$ & $46.50(0-660)$ & $60.00(0-530)$ & $17.80(0-110)$ & $5000.0 \mu \mathrm{g} / \mathrm{l}$ & EPA (1972) \\
\hline Arsenic $(\mu \mathrm{g} / 1)$ & $1.60(1-4)$ & $9.60(1-100)$ & $3.40(1-13)$ & $200.0 \mu \mathrm{g} / \mathrm{l}$ & EPA (1972) \\
\hline Cadmium $(\mu \mathrm{g} / 1)$ & $10.80(3-50)$ & $5.60(1-10)$ & $8.10(2-28)$ & $50.0 \mu \mathrm{g} / 1$ & EPA (1972) \\
\hline Chromium $(\mu \mathrm{g} / 1)$ & $4.00(0-10)$ & $12.50(0-120)$ & $2.20(0-10)$ & $1000.00 \mu \mathrm{g} / 1$ & EPA (1972) \\
\hline Cobalt $(\mu \mathrm{g} / \mathrm{l})$ & 0 & $0.50(0-6)$ & 0 & $1000.0 \mu \mathrm{g} / \mathrm{l}$ & EPA (1972) \\
\hline Copper $(\mu \mathrm{g} / 1)$ & $4.00(1-22)$ & $4.50(0-21)$ & $2.60(1-9)$ & $500.0 \mu \mathrm{g} / 1$ & EPA $(1972)$ \\
\hline Iron $(\mu g / 1)$ & $90.00(10-1100)$ & $90.00(10-590)$ & $52.00(10-120)$ & No limit & Dyer and Johnson (1976) \\
\hline Lead $(\mu \mathrm{g} / 1)$ & $166.00(27-490)$ & $93.00(6-220)$ & $121.00(22-350)$ & $100.0 \mu \mathrm{g} / 1$ & Dyer and Johnson (1976) \\
\hline Manganese (mg/l) & $0.03(0-0.13)$ & $0.32(0-3.60)$ & $0.35(0-3.00)$ & $500.0 \mathrm{mg} / 1$ & Weeth $(1973)$ \\
\hline Mercury $(\mu \mathrm{g} / 1)$ & $0.01(0-0.1)$ & $0.10(0-1.0)$ & $0.06(0-0.2)$ & $1.0 \mu \mathrm{g} / \mathrm{l}$ & EPA (1976) \\
\hline Silica (mg/l) & $3.55(0.1-19.0)$ & $4.89(0.2-18.0)$ & $3.16(0.4-14.0)$ & $48.0 \mathrm{mg} / \mathrm{l}$ & Stephenson (1973) \\
\hline Zinc $(\mathrm{mg} / \mathrm{l})$ & $0.02(0.01-0.07$ & $0.03(0.01-0.05)$ & $0.01(0.01-0.03)$ & $25.0 \mathrm{mg} / 1$ & EPA (1972) \\
\hline Nitrate (mg/l) & $0.04(0.01-0.16)$ & $0.27(0.01-1.50)$ & $0.26(0.01-2.10)$ & $300.0 \mathrm{mg} / 1$ & Olson et al. (1980) \\
\hline Sodium (mg/l) & $433.65(32-1340)$ & $765.83(60-3950)$ & $250.67(8-600)$ & $3933.0 \mathrm{mg} / 1$ & Weeth (1973) \\
\hline Calcium (mg/l) & $100.80(14-314)$ & $66.42(6.227)$ & $49.44(19-136)$ & $1000.0 \mathrm{mg} / 1$ & Hart (1974) \\
\hline Sulfate $(\mathrm{mg} / \mathrm{l})$ & $1246.00(290-4900)$ & $1788.00(120-9100)$ & $529.00(28-920)$ & $2500.0 \mathrm{mg} / 1$ & Digesti \& Weeth (1976) \\
\hline Chloride (mg/1) & $14.60(3-49)$ & $25.25(3-156)$ & $8.00(3-19)$ & $6030.0 \mathrm{mg} / 1$ & Weeth (1973) \\
\hline $\operatorname{TDS}(\mathrm{mg} / \mathrm{l})^{2}$ & $2188.50(660-7100)$ & $2706.67(340-14000)$ & $2071.11(180-2100)$ & $7000.0 \mathrm{mg} / 1$ & Olson et al. (1978) \\
\hline pH & $8.63(7.78-9.39)$ & $8.32(6.92-9.18)$ & $8.56(8.03-9.00)$ & $9.0^{3}$ & EPA (1972) \\
\hline
\end{tabular}

$11 \mathrm{mg} / 1$ is equal to $1000 \mu \mathrm{g} / \mathrm{l}$.

2TDS = total dissolved solids.

${ }^{3}$ This value for $\mathrm{pH}$ was recommended for protection of the aquatic environment. 
and Johnson 1976) and the average concentrations of lead in coal surface mine impoundments and livestock ponds also slightly exceeded this limit. The highest concentration of cadmium found in coal surface mine impoundments was equal to the safe maximum reported for this element (EPA 1972).

Otherwise, concentrations for all other elements and compounds tested for in this study were within the limits considered safe for livestock drinking water (Ballantyne 1957, EPA 1972, Stephenson 1973, Weeth 1973, Hart 1974, Dyer and Johnson 1976, Olson et al. 1980).

\section{Discussion}

Age of impoundments was not related to the differences in the water quality from this study. Based on Tukey's test, the similarities among impoundment types of water quality parameters which were different, were not the same nor consistent with differences in ages of impoundments. However, age of impoundments could not effectively be separated from type of impoundment, so the importance of age should not be dismissed. Age of impoundments in this study reflects the history of surface mining activities in the Northern High Plains. Gilley et al. (1976) could not identify trends in water quality in coal surface mine impoundments less than 4 years in age nor more than 25 years of age.

The use of surface mine impoundments for livestock watering is of considerable interest in the arid Northern High Plains. Coal and/or bentonite surface mine impoundments and livestock ponds in this region usually contain water suitable for drinking by livestock and wildlife. With few exceptions, the sources of water in this study met or did not exceed most of published tolerance limits for water quality for livestock and/or wildlife.

Depth of $0.5 \%$ light penetration was used as an indicator of turbidity in this study. Turbidity in livestock waters is in itself not generally a problem, although livestock could conceivably be affected by drinking muddy water (Soiseth 1975). Bentonite surface mine impoundments were the most turbid, although all 3 types included some impoundments that were very turbid.

Excess salts in livestock drinking water can cause death to livestock. Guidelines have been developed (Soiseth 1975, Olson et al. 1978) which indicate that TDS less than $4,000 \mathrm{mg} / 1(\mathrm{mg} / \mathrm{l}$ approximately equals ppm) should be acceptable for livestock; less than $7,000 \mathrm{mg} / \mathrm{l}$ may cause temporary diarrhea, or animals may temporarily refuse to drink. Concentrations of higher than 7,000 $\mathrm{mg} / 1$ TDS can impede growth and milk production, and may cause death in all classes of livestock (Olson et al. 1978). Specific conductivity (SC), which is easy to measure, can be converted to approximate TDS. Soiseth (1975) reported that for southeastern Montana TDS $=0.819$ (SC) -86.9 ; the results of this study indicated TDS = $1.01(S C)-299,\left(R^{2}=0.95\right)$. Because of the high TDS levels reported for some surface mine impoundments, these waters should be tested before they are used for livestock.

Digesti and Weeth (1976) reported that sulfates in water for livestock can cause changes in the blood composition and renal function of cattle and that $2,500 \mathrm{mg} / 1$ was close to a safe tolerance for sulfates in livestock water. Paterson et al. (1979) and Anderson and Stothers (1978) have reported safe consumption of water containing over $3,000 \mathrm{ppm}$ sulfate by pigs. The recommendation of Digesti and Weeth (1976) was based on data from their research on cattle, and so was accepted here. Sulfate levels above this limit were found in this study. However, since other anions are also present with sulfate, it would be likely that TDS would become a problem to the quality of drinking water for livestock before sulfates (O.E. Olson, Brookings, S. Dak., personal communication) for impoundments in the Northern High Plains. Both types of surface mine impoundments should be evaluated before they are used for livestock drinking water.

Excess concentrations of lead in drinking water can cause lead poisoning. Documented cases of lead poisoning in animals have occurred in water containing $2,400 \mu \mathrm{g} / \mathrm{l}$ of lead Pierse (1938). The highest level of lead reported here was $0.490 \mathrm{mg} / 1(490 \mu \mathrm{g} / \mathrm{l})$.
However, some impoundments of all 3 types contained lead concentrations which exceeded the recommended level ( $100 \mu \mathrm{g} / 1$ Dyer and Johnson 1976). Therefore, it might be prudent to test livestock waters in this region for lead. Although concentrations of some elements in impounded water sources can be related to concentrations in the atmosphere (Frasier 1983), concentrations of elements in waters from mine impoundments were related to spoil characteristics (McWhorter et al. 1975) or to the ground water (Wangsness 1977).

Cadmium in this study only reached the recommended maximum safe concentration in coal surface mine impoundments. Cadmium concentrations in one coal surface mine impoundment near Coalstrip, Mont., exceeded the recommended levels for livestock in only one sample (Goering and Dollhopf 1982). Therefore, it is unlikely that cadmium concentrations in livestock waters would be a problem.

\section{Conclusion}

Of the 27 water quality parameters evaluated in this study, 8 showed significant differences among impoundment types. These differences could not be related to age of the impoundments. Concentrations of 4 parameters - sulfate, TDS, lead, and cadmium-were equal to or exceeded the recommended safe levels reported in the literature for livestock drinking water. Because other anions are present in these waters, TDS is probably the best indicator of water quality and should be tested for in water from surface mine impoundments prior to use for livestock. Specific conductivity can be used to estimate TDS by the formula TDS = 1.01 (SC) - 299. Lead concentrations might also be above the recommended safe levels in some impoundments, but these concentrations should not be enough to cause severe health problems to livestock.

\section{Literature Cited}

Alsayegh, A.Y., C.L. Hanson, and C.J. Erickson. 1966. Salt balance in livestock pond waters. S. Dak. Farm and Home Res. 17:20-22.

American Public Health Association. 1975. Standard methods for the examination of water and waste water. Amer. Pub. Health Ass., Washington, D.C.

Anderson, D.M., and S.C. Stothers. 1978. Effects of saline water high in sulfates, chlorides and nitrates on the performance of young weanling pigs. J. Anim. Sci. 47:900-907.

Ballantyne, F.E. 1957. Drinking waters toxic to livestock. Can. J. Comp. Med. 21:254.

Digesti, R.D., and H.J. Weeth. 1976. A defensible maximum for inorganic sulfate in drinking water of cattle. J. Anim. Sci. 42:1498-1502.

Dyer, I.A., and R.J. Johnson. 1976. Water quality for livestock: A review of the CAST task force report. Vet. Tox. 18:65-70.

Environmental Protection Agency. 1972. Water quality criteria. U.S. Gov. Print. Off., Washington, D.C.

Environmental Protection Agency. 1976. Quality criteria for water. U.S. Gov. Print. Off., Washington, D.C.

Frasier, G.W. 1983. Water quality from water-harvesting systems. J. Environ. Qual. 12:225-231.

Gilley, J.E., G.W. Gee, and A. Bauer. 1976. Water quality of impoundments on surface-mined sites. N. Dak. Farm Res. 34:37-39.

Goering, J.D., and D.J. Dollhopf. 1982. Evaluation of a mine pit water impoundment in the semiarid Northern Great Plains. Mont. Agr. Exp. Sta. Bull. 748, Bozeman.

Hart, B.T. 1974. A compilation of Australian water quality criteria. Aust. Water Res. Council Tech. Paper No. 7. Aust. Gov. Pub. Ser. Canberra.

McWhorter, D.B., R.K. Skogerboe, and G.V. Skogerboe. 1975. Water quality control in mine spoils - Upper Colorado River Basin. U.S. Environmental Protection Agency 670/2-7-048.

Nie, N.H., C.H. Hull, J.G. Jenkins, K. Steinbrenner, and D.H. Bent. 1975. SPSS: Statistical package for the social sciences. McGraw-Hill, Inc.

Olson, O.E., C.W. Carlson, L.B. Embry, R.J. Emerick, and R.C. Wahlstrom. 1978. Water for livestock. S. Dak. Farm Home Res. 24:11-12.

Olson, O.E., R.J. Emerick, and L. Lubinus. 1980. Nitrates in livestock waters. S. Dak. State Univ. Coop. Ext. Serv. Bull. FS 603, Brookings. 
Paterson, D.W., R.C. Wahlstrom, G.W. Libel, and O.E. Olson. 1979. Effects of sulfate in water on swine reproduction and young pig performance. J. Animal Sci. 49:664-667.

Pierse, R.R. 1938. Some cases of interest met with in practice: Chronic lead poisoning (in cows). Vet. Record. 50:144-146.

Soiseth, R.J. 1975. Runoff and reservoir quality for livestock use in southeastern Montana. J. Range Manage. 28:344-348.

Steel, R.G.D., and J.H. Torrie. 1960. Principles and procedures of statistics with special reference to the biological sciences. McGraw-Hill Book Co., Inc., New York.
Stephenson, G.R. 1973. Stock-water development from shallow water ayuifer systems on southwest Idaho rangeland. p. 156-168. In: H.F. Mayland, ed. Water-Animal Relations Proceedings, Kimberly, Idaho.

Wangsness, D.J. 1977. Physical, chemical, and biological relations of four ponds in the Hidden Water Creek strip-mine area, Powder River Basin, Wyoming. U.S. Geol. Surv. Water-Resources Investigation 77-72.

Weeth, H.J. 1973. Non-applicability of federal water quality standards when applied to cattle. p. 9-12. In: H.F. Mayland, ed. Water-Animal Relations Proceedings, Kimberly, Idaho. 